\title{
Faculty development in teaching and learning: The UK framework and
}

\section{current debates}

\author{
Paul Hibbert ${ }^{\mathrm{a}} \&$ Mirko Semler ${ }^{* \mathrm{~b}}$ \\ ${ }^{a}$ School of Management, University of St Andrews, Fife, UK; ${ }^{b}$ School of Management, University \\ of St. Andrews, Fife, UK.
}

\section{Address for correspondence:}

School of Management, University of St Andrews

The Gateway, North Haugh, St Andrews, Fife, KY16 9RJ, UK

T: +44 (0)7835219669

E: $\underline{\text { ms227@ st-andrews.ac.uk }}$

Following the publication of a recent report, commissioned by the Higher Education Academy and conducted by SEDA, this short paper considers the HEA UK Professional Standards Framework in the UK Higher Education Sector, in the context of recent and continuing debates about how best to support faculty professional development in teaching (and supporting learning). The need for a framework is briefly articulated, followed by a description of its main elements and a summary of recent evidence on its impact. A discussion of issues and (international) debates about the role of formal qualifications in delivering the kind of faculty development envisaged in the framework and aligned programmes is then presented. The paper concludes with some suggestions for research that arise from this review.

Keywords: adult learning; faculty development; higher education; professionalization; teaching

${ }^{*}$ Corresponding author. Email: ms227@st-andrews.ac.uk 


\section{Introduction: The rationale for a framework}

It is, unsurprisingly, accepted that it is Universities and other Higher Education Institutions (HEIs) that bear the responsibility for making sure that their students are taught well (Beath Poyago-Theotoky \& Ulph, 2011; Cheng, 2011). While standards in teaching and learning can be assessed through a range of outcome measures focussed on student achievement, a more fundamental approach focuses on the capability of faculty and how their abilities are developed.

However, there is an overlap between outcomes and faculty capability. Arguably, the obligation to provide faculty academic / professional development in order to ensure good quality teaching and learning is closely connected with the task of ensuring educational outcomes (Onsman, 2011). In other areas of teaching (e.g. from kindergarten through to highschool teaching), this association is underlined by the fact that recognised and formal qualifications are mandatory. This is not the case at the higher education level in the UK, nor indeed in other nations (Onsman, 2009; 2011). But there are suggestions that a lack of mandatory standards is beginning to be opened up to questioning and may change in the future (Shrives, 2012). In the global marketplace of higher education, both governments and students are increasingly demanding more accountability from HEIs (Comodromos \& Ferrer, 2011), including expectations that they prove that their provision of teaching meets certain standards (Onsman, 2008).

This brief paper reviews the UK response to the need for recognised professional standards for faculty development: the UK Professional Standards Framework (UKPSF, in the following also referred to as 'the framework') as codified by the Higher Education Academy (HEA) and endorsed by Guild HE and Universities UK (HEA, 2014). Accordingly, the 
remainder of the paper proceeds in four parts. First the framework is explained, including an account of its main features. Second, the impact of the framework is considered, based on published data about its application and take-up and commentary across different HEIs, as detailed in recent publicly available reports. Third, emerging debates for and against the organisation of faculty development around this kind of framework are discussed. Finally, some questions for further inquiry are suggested.

\section{The UKPSF}

The framework was introduced in 2006 in response to a growing call for standards and professionalization in university teaching (HEA, 2013) and revised as a result of consultations across the sector ${ }^{1}$ (Law, 2011). The framework addresses all bodies with an interest in teaching and supporting learning in Higher Education in the UK. The purpose of the framework is to improve the quality of teaching and learning support and ultimately, to enhance students' learning experience (HEA, 2012a). It 'provides a means to comprehensively benchmark, develop, recognise and reward teaching and learning support roles in higher education' (HEA, 2013, p6). Its goals are to (HEA, 2012a, p. 2):

- Promote the professionalization of teaching and learning support

- Foster creative and innovative approaches to teaching and learning

- Enable HE staff to gain recognition and reward

- Facilitate and support the design and delivery of programmes and activities

- Demonstrate professionalism to stakeholders 
- Support senior staff in developing policies and promoting a strong culture of excellence in teaching and learning support (see also: HEA, 2013).

The HEA offers a recognition and accreditation service and it awards, depending on the role and experience of the faculty member, the following fellowships: Associate Fellow, Fellow, Senior Fellow, and Principal Fellow (2012a; 2012b). These fellowships provide four ways of envisaging and enacting the two major elements of the framework: (1) descriptors and (2) dimensions. (1) Descriptors 'are a set of statements outlining the key characteristics of someone performing four broad categories of typical teaching and learning support roles within Higher Education' (HEA, 2012b, p1) - that is, one of the categories of fellowship. (2) The Dimensions of Practice identify what someone performing teaching or supporting learning should be able to evidence (HEA, 2013).

The descriptor for each category of fellowship begins with a statement that indicates the level of understanding required for the performance of teaching and learning support role of that type at an appropriate standard within a higher education institution' (HEA, 2012b, p. 1). The general statements are followed by further statements (between five and seven) drawn from the second component of the framework (dimensions) and stipulate, 'what someone performing such roles should be able to evidence' (HEA, 2012b, p. 1). In a way the descriptors reflect a career path, through professional development in teaching, and correspond to different roles a practitioner in Higher Education might move through. The framework thus outlines an incremental progression (HEA, 2012b, p. 2; Peat, 2014):

- Descriptor 1, Associate Fellow: typically those who are relatively new to teaching, or those with limited (and/or specialist) roles related to teaching support 
- Descriptor 2, Fellow: typically individuals with significant teaching responsibilities in a range of settings and roles, including most mainstream academics

- Descriptor 3, Senior Fellow: typically those with leadership, management or mentoring roles in relation to teaching and learning, often across a department or subject group

- Descriptor 4, Principal Fellow: typically individuals with wide-ranging, strategic, institutional roles in relation to teaching and learning

Alternatively, for instance if there is no clear career path or the context is different, individuals may seek the type of recognition that reflects their current role or the role they seek to be recognised as competent for. The latter element is crucial to the faculty development role of the framework. Each Descriptor thus indicates opportunities for personal development that may go beyond the current role an individual occupies. In that sense, the framework 'provides the means of articulating the individual's progress in terms of developing knowledge, expertise, impact, influence and leadership in teaching and supporting learning' (HEA, 2012b, p. 3). For these reasons, achievement of a particular fellowship grade may be associated with one of two routes to recognition.

The first is through formal qualifications. The most common formal qualification is a post-graduate certificate in teaching in higher education (although other titles for such programmes also exist). These programmes are equivalent to one-third of a masters degree credits and are formally accredited by the HEA. Content within the accredited framework varies, but may include (for example): an introduction to teaching and learning in higher education; (adult) learning theory and supporting student learning; curriculum design and assessment; 
reflective practice for teaching (such as peer observations and discussions); research student supervision; and subject-specific specialisations, such as teaching in STEM subjects. This type of qualification (the PgCertTHE) entitles the holder to the most-awarded Fellowship category of the HEA (FHEA). Students may extend their studies to a postgraduate diploma or a full masters degree, but this does not provide automatic entitlement to a different grade of fellowship.

The second route to recognition is through an assessment of experience, involving a submission with evidence compiled by the applicant and accompanied by referee reports. This assessment compares the applicant's evidence to the framework descriptor for a particular fellowship category. Thus there is no presumption that a formal qualification is essential for professional development, although some HEIs nevertheless make such qualifications mandatory for their faculty. However, for higher fellowship grades (SFHEA/PFHEA) assessment of experience is the only available route.

The dimensions of the framework define and distinguish descriptors and help to reflect the complexity and multi-faceted character of the professional role of staff involved in teaching and supporting learning. The dimensions are statements categorised into three elements (Figure 1):

Insert Figure 1 about here

Figure 1. Dimensions of the UKPSF (Source: adapted from HEA, 2011)

As figure 1 suggests, the components are argued to be inter-related and represent the multi-dimensionality of practicing teaching and supporting learning (HEA, 2012c). Table 1 specifies each dimension and its sub-categories.

Insert Table 1 about here

Table 1. Dimensions of the framework and their components (Source: HEA, 2012c; 2011) 


\section{The reach and impact of the UKPSF}

Importantly, while the UKPSF is recognised across the sector it is not universally mandatory. In particular, many institutions do not require established staff (employed before the framework was developed) to seek recognition (Shrives, 2012), and some institutions do not require that any staff seek recognition. Some observers suggest that obtaining HEA fellowship is increasingly a requirement for new academic staff at many institutions (Creanor, 2011; Norton, Aiyegbayo, Harrington, Elander \& Reddy, 2010). Overall the result has been that, between 2004 and 2012, the total number of awarded Fellowships grew by $145 \%$ to a total of 36,557 (HEA, 2013, p. 10). However, data collated by the Higher Education Statistics Agency (HESA) shows that this is only a fraction of the total academic staff employed in HEIs (see Table 2).

Insert Table 2 about here

Table 2. Staff by activity group and mode of employment 2012/2013 (HESA, 2014a; 2014b)

HESA (2014a) reports that in 2012/2013 of the academic staff listed in Table 2, 46,795 were involved with teaching and 94,600 with research and teaching (the remainder being solely concerned with research and administration). In other words, out of the 141,395 academic staff members involved in teaching in, $26 \%$ had achieved accreditation from the HEA within the UKPSF. This is perhaps relatively strong take-up, given the non-compulsory status of the framework and the fact that the majority of faculty currently in the sector were already in permanent positions before the framework was established. 
In addition to initial accreditation, the role of the framework in guiding continuing professional development (CPD) for faculty needs to be considered. Recent survey results (HEA, 2013) involving 1,201 respondents from UK-based HEIs show that $47.4 \%$ of the respondents had some substantial knowledge of the UKPSF. The same study reveals that from the respondents, $34 \%$ had visited seminars or courses related to the framework. However, some respondents who held a Fellowship and/or had completed formal certification courses reported no awareness of the UKPSF. This indicates untapped potential for the framework within the UK Higher Education sector, as a guide to CPD and faculty development in general. As a consequence, the HEA ran events in 2013/2014 to promote the UKPSF.

Some studies suggest why the penetration of formal faculty development is relatively low. It has been suggested that institutional and individual resistance against formal faculty development exists (Quinn, 2012). In addition, participants in the HEA's impact study (HEA, 2013) voiced concerns that formal faculty development reduced time for research and teaching commitments.

Despite the opportunity for improved awareness, overall the HEA has reported (2013) a fairly significant impact of the framework on teaching practice across different HEIs. $86.4 \%$ of respondents to the HEA study reported that teaching and learning support practices within their institutions have changed and evidence of that change is partly $(40.7 \%)$ publicly available (HEA, 2013, p. 14). The study reported that the UKPSF has, for example changed the design of subject materials, the institutional framework for professional development and internal policies and strategy documents in many institutions (HEA, 2013, p. 15). Furthermore, among the institutions participating in the study it appears that the trend is to "require engagement with the UKPSF via accredited courses for newly appointed academics' (HEA, 2013, p. 30) and to create 
opportunities for mid-career and senior staff members to engage with the framework. Early career teachers and teaching $\mathrm{PhD}$ students are increasingly required to seek accreditation from HEA in many HEIs. While the institutions in the study were at different stages of implementing the framework in their policies, certain focussed areas of that engagement were apparent (HEA, 2013, p. 31):

- Teaching quality processes

- Alignment with CPD frameworks

- Performance management and appraisal schemes

- Promotion (especially to senior lecturer)

- Reward and recognition schemes (related to HEA Fellowship)

Focussing on individual faculty, the HEA (2013, p.26) report revealed that engagement with UKPSF had changed how participants think about and undertake learning, teaching and assessment, and the way that people in the institution talk about and act upon these responsibilities (c.f. Hanbury, Prosser \& Rickinson, 2008). Notably, respondents who had completed seminars or courses related to the UKPSF report significant changes in their thought process and engagement with learning, teaching, and assessment (HEA, 2013, p. 28). This is concordant with research that shows that formal faculty development encourages participants to become more student-centred in their teaching approach (Hanbury et al., 2008). Furthermore, the respondents felt that the framework strengthens their confidence and identity as teachers and learning supporters (c.f.: Butcher \& Stoncel, 2012; Norton et al., 2010; Stewart, 2014), and in research-focused institutions where teaching-focused roles can be 'lower profile', it enhances the understanding of what it means to be a professional educator (Peat, 2014). For all faculty, the 
framework 'puts teaching on the map', and provides a common language for discussing it, in a changing environment (Law, 2011). But of 1,250 respondents employed in the UK Higher Education sector, only $28.4 \%$ had received reward or recognition on the basis of teaching or student support work (HEA, 2013, p. 24).

While the UKPSF is the generally recognised standard, there are other relevant frameworks important for particular faculty in UK HEIs, such as the Staff and Educational Developers Association (SEDA) framework, Quality Assurance Agency codes, and disciplinespecific standards (for further details, see HEA, 2013, p. 19). The HEA (2013) suggests that, especially with regards to accreditation processes, integration and alignment should be pursued in order to reduce barriers on an institutional level. In general the embedding process of the framework seems to be driven particularly by senior managers, internal peer pressure and support, and a central academic development unit. The study finds that external pressure may facilitate the integration process but not from the HEA, as it cannot exert any power on institutions (since it is a collaborative supporting body, and not a regulator).

Given the significant take-up of the framework despite its voluntary status and large numbers of long-established faculty who have no particular incentive to become involved with CPD, over time it could reasonably be expected that the framework will become a de-facto universal standard in the UK sector.

\section{Debates about formal faculty development}

Although the preceding section has painted a picture of the growing acceptance of the UKPSF, looking at debates on faculty development - debates that are international in content and outlook, 
since higher education is increasingly seen as a 'global market' - some of the principles are matters of contention. Most particularly, the need for and effectiveness of formal programmes and qualifications has long been contested. Davidson (2004) takes a negative view, arguing that professionalism should not be equated with 'credentialism'. Similarly an earlier study by McArthur, Earl and Edwards (2004) found no major difference between formally trained and not formally trained cohorts within a single institution. Thus it is perhaps unsurprising that Onsman (2009) argues that certificate programmes are simply convenient tick-boxes for institutions and that shorter training courses at the point of need and/or on-the-job learning are more useful. However, some report that early career faculty do find formal programmes to be useful (Norton et al., 2010; Onsman, 2006; Stewart, 2014) while others suggest that initial enthusiasm is later replaced by disappointment (Knight, 2006).

Whether training and newly adopted teaching methods actually translate into better teaching and learning (c.f. Stes, De Maeyer, Gijbels, \& Van Petegem, 2013) continues to be contested (see Stes, Min Leliveld, Gijbels \& Van Petegem, 2010, for a review). This perhaps relates to Trowler and Cooper's (2002) finding that the ability to translate learning outcomes from formal qualifications into improved teaching practice depends on the fit with the institutional context, an insight that has been reinforced and developed by others (c.f. Mathieson, 2011; Shrives, 2012; Warhust, 2008). Similarly, with a sharper focus on the UK context and framework, recent research has highlighted institutional constraints that work against creative teaching and learning approaches. In particular, the prioritisation of research and related community norms favour teaching that is 'just good enough' (Creanor, 2011; Lucas \& Turner, 2007; Norton et al., 2010; Stewart, 2014). Thus there may be little at fault in formal certificate programmes as the enthusiasts empowered by them have to battle hostile institutional climates. It 
is this climate that may hinder the universal adoption of formal qualifications and instead favour professional development through informal, experiential routes.

A pertinent issue that nevertheless arises from the critique of qualifications above is how faculty teaching competence might be developed experientially without participation in a formal qualification program, and what the requisite processes of socialisation to accomplish this might involve. Madhavaram and Laverie (2010) have a vision of a relational, experiential trajectory that does not require a formal program; their vision is that one develops such competence 'through learning from (explicit knowledge transfer) and/or interacting (tacit knowledge transfer) with institutions, academic researchers, [discipline-specific] educators, practitioners, educators from other fields, and students' (p. 203). Similarly Roxå \& Mårtensson (2009) advocate learning through conversations in small 'significant networks'. But if a formal programme is not used to structure experiential learning, then this leaves the individual academic with a need for considerable reflective practice (c.f. Mathieson, 2011) to evaluate and integrate insights from such diverse sources (Warhust, 2008).

In line with Collin and Valleala's (2005) finding that both individual and social elements of learning are equally important to faculty development, Knights, Meyer and Sampson (2007) suggest that reflective practice is best situated in the context of team-teaching, 'where two academics or more are present with the students for the whole of the course $[\ldots$ which...] provides more possibilities for fruitful peer reflection' (p. 240). But others have suggested aspects of a hybrid approach are emerging, in which reflective practice is both integrated with a formal programme (fitted to a local context, c.f.: Shrives, 2012; Stes, 2013; Quinn, 2012), and taken up as an approach to ongoing, long-term development (Lucas \& Turner, 2007; Stewart, 2014). 
Another common approach to informal faculty development - compatible with reflective practice - is through mentoring. This is also argued to help junior faculty to navigate their political (institutional) contexts and connect their understandings with the 'real world' of practice (e.g. Devos, 2007; Helyer \& Lee, 2012). However, there are also areas where mentoring in teaching and learning is lacking, particularly in relation to doctoral students and the guidance that they receive from supervisors (Jepsen, Varhegyi \& Edwards, 2012), who are predominantly focussed on the research aspects of their careers.

Overall, it seems that there is room for more thought about the kinds of informal processes that can support faculty development in teaching and supporting learning, and how these might be enabled and enacted.

\section{Conclusions}

Arguably the case for faculty development and professionalism in teaching and supporting learning is not contested, and the UKPSF is a recognised framework that is increasingly accepted as the benchmark in the UK sector. However, debates continue about the relevance and effectiveness of formal qualifications for faculty development. With these debates in mind, there are three pertinent questions that would benefit from further research.

First, if formal qualifications are accepted and useful in other professions, is contention about certified programmes for university teaching really derived from the content of programmes or the nature of the profession? Evidence from recent studies suggests that the institutional climate of higher education might be problematic (Creanor, 2011; Lucas \& Turner, 
2007; Norton et al, 2010; Stewart, 2014), and comparison with different professional bodies of knowledge in other organisational climates might illuminate this issue.

Second, does the relatively low perceived impact of certified programmes suggest that research on adult learning needs further development, or that this research needs to be translated more quickly into certificate programmes? Studies reviewing the research base of certificate programmes and the balance between the 'basics' and 'cutting edge' themes could be helpful in suggesting new developments.

Third, if informal learning about teaching and supporting learning is equivalent in effectiveness to formal programmes, is there some productive way in which the two approaches might be blended, as the insights of Stewart (2014) suggest? Detailed comparisons between existing programmes that have different levels of focus on reflective approaches would yield useful insights.

Other areas of research could also be considered, but overall there seems to be room for thought about how faculty development in teaching and learning might involve professional development framework(s) and formal qualifications that: reflect how professional knowledge varies between disciplines; balance basic pedagogy with cutting-edge themes in adult learning research; and employ more action learning and reflective practice strategies, not least because these could drive continuing development.

\section{Disclosure statement:}

This research received no funding from public or private sector bodies, and there are no financial or other conflicts of interest associated with it.

\section{Notes on contributors}


Paul Hibbert is Professor of Management at the University of St Andrews and a Visiting Professor at the University of Queensland. His research is principally concerned with collaborative and relational processes of organizing and learning.

Mirko Semler is a Ph.D. candidate at the School of Management at the University of St Andrews. His research is primarily concerned with the formation and effects of social networks in the context of social entrepreneurship.

\section{References}

Beath, J., Poyago-Theotoky, J., \& Ulph, D. (2012). University funding systems: Impact on research and teaching. Economics: The Open-Access, Open-Assessment E-Journal, 6, 1-24. Retrieved from: http://www.economics-ejournal.org/economics/journalarticles/2012-2

Butcher, J., \& Stoncel, D. (2012). The impact of a postgraduate certificate in teaching in higher education on university lecturers appointed for their professional expertise at a teaching-led university: 'It's made me braver'. International Journal for Academic Development, 17, 149-162. doi:10.1080/1360144X.2011.620107.

Cheng, M. (2011). The perceived impact of quality audit on the work of academics. Higher Education Research \& Development, 30, 179-191. Retrieved from: http://ahero.uwc.ac.za/index.php? module $=$ cshe\&action=downloadfile $\&$ fileid $=18409092513$ 141101196856.

Collin, K., \& Valleala, U.-M. (2005). Interaction among employees: How does learning take place in the social communities of the workplace and how might such learning be supervised? Journal of Education and Work, 18, 401-420. doi:10.1080/13639080500327873

Comodromos, G., \& Ferrer, J. (2011). Incremental institutional change and Australian universities. International Review of Business Research Papers, 7, 330-339. Retrieved from: http://www.bizresearchpapers.com/25.\%20George\%20Comodromos-FINAL.pdf.

Creanor, L. (2011, December). Scholarship, leadership and technology: a case study of embedding evidence-based practice. Paper presented at the Ascilite conference, Hobart.

Davidson, M. (2004). Bones of contention: Using self and story in the quest to professionalize higher education teaching - an interdisciplinary approach. Teaching in Higher Education, 9, 299-310. doi:10.1080/1356251042000216624.

Devos, A. (2007). Mentoring and the new curriculum of academic work. Journal of Organisational Transformation and Social Change, 4, 225-235. doi:10.1386//jots.4.3.225/1. 
Hanbury, A., Prosser; M. \& Rickinson, M. (2008). The differential impact of UK accredited teaching development programmes on academics' approached to teaching. Studies in Higher Education, 33, 469-483. doi:10.1080/03075070802211844.

HEA (2011). The UK Professional Standards Framework for teaching and supporting learning in higher education. York: HEA. Retrieved http://www.heacademy.ac.uk/assets/documents/ukpsf/UKPSF_2011_English.pdf.

HEA (2012a). Framework guidance note I: What is the UK Professional Standards Framework?. York: HEA. Retrieved from: http://www.heacademy.ac.uk/assets/documents/ukpsf/framework-guidance-1.doc.

HEA (2012b). Framework guidance note 2: What are the UK Professional Standards Framework descriptors? York: HEA. Retrieved from: http://www.heacademy.ac.uk/assets/documents/ukpsf/framework-guidance-2.doc.

HEA (2012c). Framework guidance note 3: What are the dimensions? York: HEA. Retrieved from: http://www.heacademy.ac.uk/assets/documents/ukpsf/framework-guidance-3.doc.

HEA (2013). Measuring the impact of the UK Professional Standards Framework for teaching and supporting learning. York: HEA. Retrieved from: http://www.heacademy.ac.uk/assets/documents/ukpsf/UKPSF_Impact_Study_Report.pdf.

HEA (2014). UKPSF terms of use policy York: HEA. Retrieved from: https://www.heacademy.ac.uk/sites/default/files/downloads/UKPSF_Terms_of_Use_Policy June_2014.pdf.

Helyer, R., \& Lee, D. (2012). Mentoring for business engagement as continuing professional development of university academic staff. International Journal of Training and Development, 16, 217-227. doi:10.1111/j.1468-2419.2012.00405.x.

HESA (2014a). Free online statistics - Staff: Statistical first release 198. Higher Education Statistics Agency. Retrieved from: https://www.hesa.ac.uk/stats-staff.

HESA (2014b). HESA SFR 198: Staff at higher education institutions in the United Kingdom 2012/13. Higher Education Statistics Agency. Retrieved from: https://www.hesa.ac.uk/sfr198.

Jepsen, D. M., Varhegyi, M. M., \& Edwards, D. (2012). Academics' attitudes towards PhD students' teaching: preparing research higher degree students for an academic career. Journal of Higher Education Policy and Management, 34, 629-645. doi:10.1080/1360080X.2012.727706.

Knights, S., Meyer, L., \& Sampson, J. (2007). Enhancing learning in the academic workplace through reflective team teaching. Journal of Organisational Transformation and Social Change, 4, 237-247. doi:10.1386/jots.4.3.237/1. 
Law, S. (2011). Recognising excellence in teaching and learning: Report from consultation on the UK Professional Standards Framework (UKPSF) for teaching and supporting learning in higher education. York: HEA. Retrieved from: http://www.heacademy.ac.uk/assets/documents/ukpsf/recognising-excellence.pdf.

Lucas, L., \& Turner, N. (2007, April). Early career academics and their perceptions and experiences of linking research and teaching. Paper presented at the Colloquium on International Policies and Practices for Academic Enquiry, Winchester.

Madhavaram, S. \& Laverie, D.A. (2010). Developing Pedagogical Competence: Issues and Implications for Marketing Education. Journal of Marketing Education, 32(2): 197-213. doi:10.1177/0273475309360162.

Mathieson, M. (2011). Developing academic agency through critical reflection: a sociocultural approach to academic induction programmes. International Journal for Academic Development, 16, 243-256. doi:10.1080/1360144X.2011.596730.

McArthur, J., Earl, S., \& Edwards, V. (2004, November/December). Impact of courses for university teachers. Paper presented at the Australian Association for Research in Education Annual Conference, Melbourne. Retrieved from: http://www.aare.edu.au/data/publications/2004/mca04419.pdf.

Norton, L., Aiyegbayo, O., Harrington, K., Elander, J., \& Reddy, P. (2010). New lecturers' beliefs about learning, teaching and assessment in higher education: the role of the PGCLTHE programme. Innovations in Education and Teaching International, 47, 345-356. doi:10.1080/14703297.2010.518426

Onsman, A. (2006, November). The relationship between participants' perceptions of time commitment, facilitator guidance and anticipated professional efficacy in a subject of a graduate certificate of higher education course: some preliminary analyses. Paper presented at the AARE Conference, Canberra. Retrieved from: http://www.aare.edu.au/data/publications/2006/ons06052.pdf. Accessed: 18 July 2014.

Onsman, A. (2008). Tempering universities' marketing rhetoric: a strategic protection against litigation or an admission of failure? Journal of Higher Education Policy and Management, 30, 77-85. doi:10.1080/13600800701745077.

Onsman, A. (2009, November/December). Carrots and sticks: Mandating teaching accreditation in higher education. Paper presented at the AARE Conference, Canberra. Retrieved from: http://www.aare.edu.au/data/publications/2009/ONS091445.pdf.

Onsman, A. (2011). Proving the pudding: optimising the structure of academic development. Journal of Higher Education Policy and Management, 33, 485-496. doi:10.1080/1360080X.2011.605223. 
Peat, J. (2014). UKPSF: A vehicle for development or hierarchical ladder? Educational Developments, 15, 16-18.

Quinn, L. (2012). Understanding resistance: an analysis of discourse in academic staff development. Studies in Higher Education, 37, 69-83. doi:10.1080/03075079.2010.497837.

Roxå, T., \& Mårtensson, K. (2009). Significant conversations and significant networks: exploring the backstage of the teaching arena. Studies in Higher Education, 34, 547-559. doi:10.1080/03075070802597200.

Shrives, L. (2012). From Postgraduate Certificates... To embedding UKPSF at all levels. Educational Developments, 13, 1-6. Retrieved from: http://www.seda.ac.uk/resources/files/publications_131_Ed\%20Devs\%2013.3\%20v4\%20(F INAL).pdf.

Stes, A., De Maeyer, S., Gijbels, D., \& Van Petegem, P. (2013). Effects of teachers' instructional development on students' study approaches in higher education. Studies in Higher Education, 38, 2-19. doi:10.1080/03075079.2011.562976.

Stes, A., Min-Leliveld, M., Gijbels, D. \& Van Petegem, P. (2010). The impact of instructional development in higher education: The state-of-the-art of the research. Educational Research Review, 5, 25-49. doi:10.1016/j.edurev.2009.07.001.

Stewart, M. (2014). Making sense of a teaching programme for university academics: Exploring the longer-term effects. Teaching and Teacher Education, 38, 89-98. doi:10.1016/j.tate.2013.11.006.

Trowler, P., \& Cooper, A. (2002). Teaching and learning regimes: implicit theories and recurrent practices in the enhancement of teaching and learning through educational development programmes. Higher Education Research and Development, 21, 221-240. doi:10.1080/0729436022000020742.

Warhust, R.P. (2008). 'Cigars on the flight-deck': new lecturers' participatory learning within workplace communities of practice. Studies in Higher Education, 33, 453-467. doi: $10.1080 / 03075070802211828$ 